SZENTMIKLÓSi Attila

DOI: 10.15170/DIKE.2020.04.01.11

Egyéni Ügyvéd

\title{
A tengeri zsákmányjog, a hatalmi szimbólumok és a tengeri csaták Kajtár István munkássága a tengerek jogtörténetéről
}

\section{The Law of Sea Plunder, Power Symbols and Naval Battles: The Work of István Kajtár on the Legal History of the Sea \\ István Kajtás's research on cultural history was extended to nautical questions as well. His work in this subject, especially his papers regarding the history of the Soviet-Russian fleet, the nautical symbol system, the law of sea plunder, the naval battle of Lepanto and the bistory of submarines will be shown in the overview honouring him.}

Keywords: legal culture, Soviet fleet, law of sea plunder, CSS Alabama, maritime orders, waship's names, armed merchant cruisers, symbols of power, Lepanto, submarines

\section{Kajtár István emlékére}

Kajtár István professzorom, mentorom és barátom volt. Összekötött minket a hajózás története és technikája iránti közös érdeklődés, mely tárgyban számos témát kutatott. A tengerek történetéről és jogtörténtéről magyar nyelven tizenkét tanulmányt tett közzé az elmúlt években. Jogtörténészi munkásságát a Pécsi Tudományegyetem Állam- és Jogtudományi Karán a Jogtörténeti Tanszék munkatársai méltó módon dolgozzák fel; ehhez szeretnék hozzájárulni azzal, hogy a hajózással kapcsolatos műveit ismertetem. Célom tanulmányainak csupán a bemutatása és nem azok elemzése. Éppen ezért az egyes írásokat nem csoportosítottam témák szerint, hanem ragaszkodtam a publikálás kronológiai sorrendjéhez.

A modern idők hadihajói mindig az adott kor technikájának csúcsát jelenítették meg. A koncentrált erő mintaképei: ezt jól jelzi az is, hogy ami a szárazföldön nehéztüzérségnek minősül, az egy csatahajón csak közepes tüzérségnek számít. ${ }^{1}$ A hadihajók a legnagyobb méretú és legdrágább harci gépezetek, hiszen elképesztően bonyolult a tengerek jelentette keserves körülmények (sós víz korrodáló hatása, a hullámok és a szél keltette mechanikai erők, erôsen változó időjárási viszonyok) között működni. Nagy nehézséget okoz a fegyverekkel már csak

\footnotetext{
${ }^{1}$ E sorok írója a kötelező katonai szolgálatát a Pécsi Tüzérdandár szervezetében töltötte el, melynek 1987-ben az egyik fô fegyvere a 152 mm-es D-20 jelű ágyútarack volt, a másik pedig egy rakéta-sorozatvetô. 45 évvel korábban a Yamato csatahajó - átépítése előtt - 12 db 155 mm-es ágyút hordozott, ami több, mint egy szárazföldi tüzérüteg teljes ágyúállománya. Fő fegyverzete azonban 9 db, háromszor akkora, azaz 460 mm-es ágyú volt.
} 
megfelelően célozni is, ${ }^{2}$ hát még célba találni, de előtte ezeket a fegyvereket a megfelelő helyre szállítani, ${ }^{3}$ azokat kiszolgálni, falunyi, olykor városnyi személyzetüket akár hónapokon keresztül ellátni, a parancsnoksággal és a flotta többi tagjával az óriási földrajzi távolságok ellenére a kapcsolatot fenntartani, az ellenséget pedig felderíteni. A feladat összetettsége miatt a tervezők igyekeznek az adott időben elérhető legfejlettebb technikát alkalmazni. ${ }^{4}$

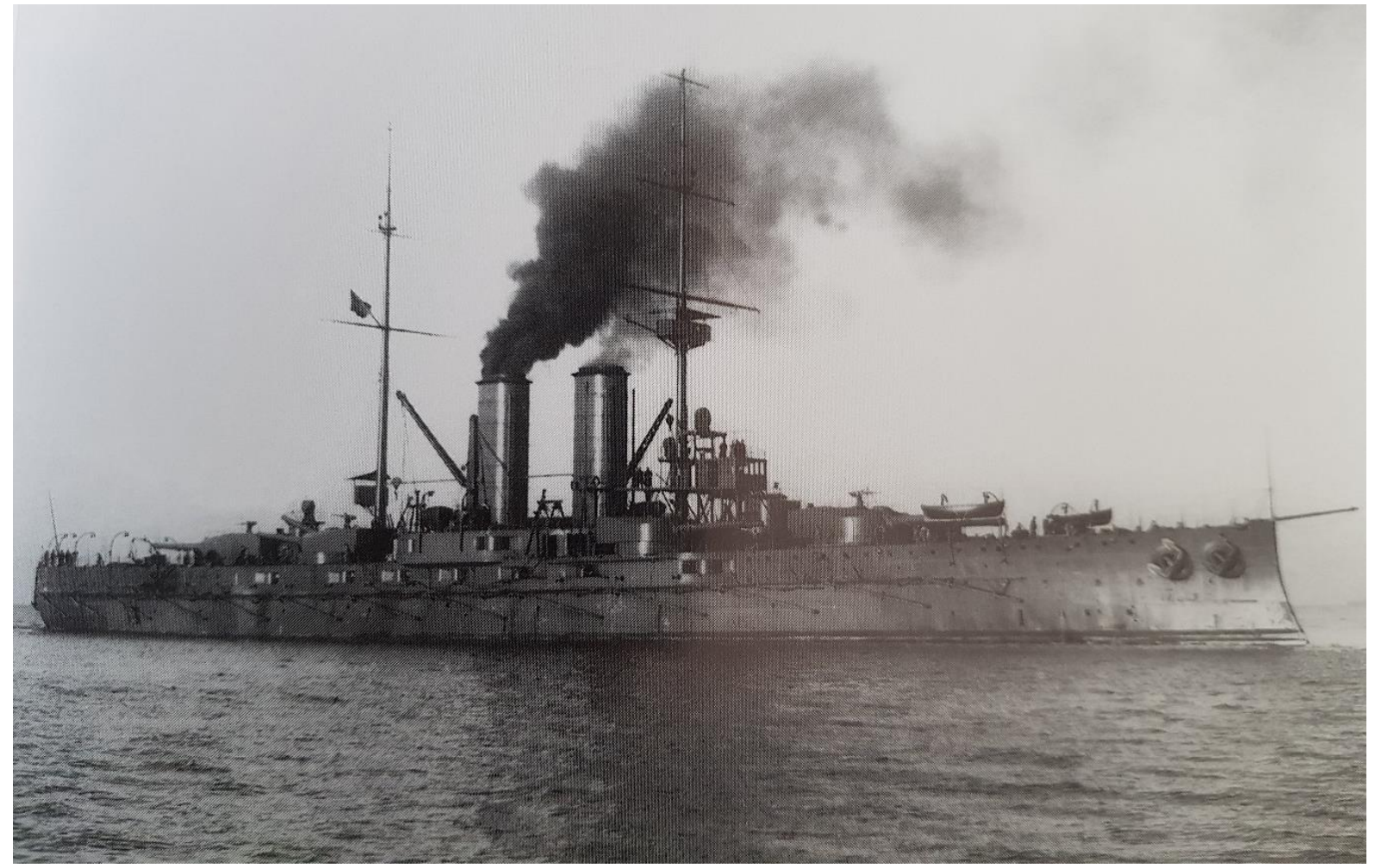

1. kép: A Zrínyi csatahajó ${ }^{5}$

\footnotetext{
2 Példának okáért a Szent István csatahajó fő fegyverzetét 305 mm-es ágyúk alkották. Egy ilyen ágyúcső 13,75 méter hosszú volt, 52,6 tonnát nyomott és 18 kilométerre lőtt el. A célzás során az ágyút hordozó hajó és a célpont is folyamatosan mozgott valamilyen irányba és valamilyen sebességgel, továbbá a hordozó hajó a tenger hátán a hullámzásnak megfelelően dőlt előre-hátra, jobbra-balra. Ezen felül számításba kellett venni a szél irányát és sebességét, a levegő páratartalmát és más tényezőket is. Mindezeket figyelembevéve kellett az ágyúcsövet (melynek hossza és súlya egy teljesen megrakott kamionnak felel meg) megfelelő irányba és magassági szögbe állítani és ott tartani úgy, hogy még évtizedekig nem állt rendelkezésre segítségként elektronikus számítógép. BALOGH-CSEPREGI, A Szent István csatahajó és a csatahajók rövid története 78 .

${ }^{3}$ A második világháborúban használt német K5-E vasúti löveg (német frontszlengben Karcsú Berta, a szövetségeseknél Anzio Annie, illetve Anzio Express) egy $280 \mathrm{~mm}$-es ágyú volt. Ennek az egyetlen fegyvernek, amely két darab, hattengelyes vasúti kocsin volt telepítve, a kiszolgálásához kellett a vasúti pálya, azon pedig egy egészen komoly, 24 kocsiból álló vasúti szerelvény és egy megfelelően nagy teljesítményű mozdony. Ilyen méretű fegyverből - mely a csatahajók fő fegyverzeteként már az első világháborúban is inkább a kisebbek közé számított - példának okáért a Gneisenau csatacirkáló egyszerre 9 db-ot szállított egy-egy összecsapáshoz. Lásd NÉMETH - SÁRHIDAI, A vasúti tüzérség általános jellemzői és egyes típusai 56-57.

${ }^{4}$ Egy atommeghajtású, ballisztikus rakétákat hordozó tengeralattjáró technikailag az űrhajókkal képvisel közeli műszaki színvonalat. A csúcstechnika miatt azonban a modern hadihajók rendkívül drágák: jellemző, hogy a Kirov atommeghajtású csatacirkáló bekerülési költségét olyan összegként jelölték meg, amiből Moszkva építhetett volna egy 150.000 fő lakosságú új várost. Lásd SZABÓ, 300 éves az orosz haditengerészet 20.

${ }^{5}$ Forrás: CSONKARÉTI, Az Osztrák-Magyar Monarchia haditengerészete 9.
} 
A hadihajók - akár a hozzájuk kapcsolódó romantikus elképzelések miatt, akár mint mérnöki mesterművek vagy csak mint az emberi tevékenység eszközei - sok ember érdeklődését felkeltik. A tengerész-hagyományokkal és tengeri kapcsolattal rendelkező országokban komoly irodalma van ennek a témának. ${ }^{6}$ Magyarországnak már egy évszázada nincs tengeri hadiflottája, a politikai elvárások pedig sokáig kizárták a Monarchia haditengerészeti hagyományainak reális értékelését. Ennek ellenére hazánkban is kialakult a haditengerészet iránt érdeklődők köre még úgy is, hogy nagy részük valószínűleg sohasem léphetett komoly hadihajó fedélzetére.

A konzervatív felfogás szerint a jogtörténetnek csupán a források feltárása, kutatása és értelmezése a feladata, míg mások mindezt „jogrégészetnek” tartják. A jogtörténet tárgyának meghatározásáról, kutatási területeinek határairól Stipta István szerint hazánkban Eckhard Ferenc 1931-es programja ${ }^{9}$ óta nem folyt érdemi vita; ́́gy az egyes szerzőktől, vagy az iskoláktól függ, hol húzzák meg a vizsgálat határait. Ezeket a határokat egyes külföldi szerzők kezdték feszegetni, ${ }^{10} \mathrm{de}$ az 1990-es évek elejétől már Magyarországon is megjelent a jogtörténeti kutatásnak egy olyan iránya, amely a vizsgálatot az érintkező tudományterületekre (az általános történelemtudományon kívül a történelmi segédtudományok - különösen a címertan, a pecséttan, az inszigniológia, az ikonológia - valamint a művelődéstörténet, az irodalom- és múvészettörténet, a szervezet- és jogszociológia valamint a nyelvtudomány) is kiterjesztette. A jogi kultúrtörténet, ezen belül különösen a jogi stílustörténet, a hatalmi jelképek, a jogtörténeti ikonográfia és a jogtörténeti szimbólumkutatás Kajtár István szerint a ,jog kulturális holdudvarát” képezi. E terület első hazai mûvelője ő maga volt.

Kajtár István előadásain rendkívül szerteágazó tudását felhasználva arra törekedett, hogy a hallgatóinak minél plasztikusabban mutassa be az adott anyag összefüggéseit; példái között gyakran feltűntek a hajózás körébe tartozó eseményekre való utalások. Ezek az előadási hivatkozások alátámasztották azt az egyetemi szájhagyományt, hogy Kajtár professzor úrnak a hajózás az egyik kedvenc témája, ám ilyen tárgyú publikációiról hallgatóként nem tudtam. Az ezredforduló után már több idôt szentelt ennek a témakörnek: speciális kollégiumot indított, ${ }^{11}$ melyhez akkori tanszéki kollégájával, Szekeeres Róbert adjunktussal közösen tansegédletet is készített. ${ }^{12}$

1992-ben egy véletlen folytán szerzett tudomást arról, hogy engem is érdekel a hadihajózás története. Miután rövid úton meggyőződött ${ }^{13}$ arról, hogy az alapvető ismeretek birtokában vagyok, felajánlotta segítségét és a témában összegyüjtött könyveit az engem érdeklő kérdésekben való elmélyedéshez. Az internet előtti korban sokkal nehezebb volt tudomást szerezni egy-egy

\footnotetext{
${ }^{6}$ Elég talán csak Siegfried Breyer vagy Helmut Pemsel nevét megemlítenem és műveikre hivatkoznom.

${ }^{7}$ E sorok írójának sem volt még szerencséje egy komoly hadihajó fedélzetére lépni - az Uss Missouri múzeummá való átalakítása ottjártamkor még nem fejeződött be, ezért nem engedtek a közelébe, a HMS Belfast cirkálót pedig éppen londoni utazásom napjaiban vitték el újrafesteni. Ám ami késik...

${ }^{8}$ STIPTA, A jogi kultúrtörténet Magyarországon 305.

${ }^{9}$ Ezen program szerint a jogtörténetnek a jogot körülvevő eszméket és a jogfejlődést befolyásoló kulturális tényezőket is vizsgálnia kellene.

${ }^{10}$ Lásd például a jogi ikonográfia témájában KOCHER, Szimbólumok és jelek a jogban, passim.

${ }^{11}$ A tengerek és a hajórás jogtörténete című szeminériumot egészen nyugdíjba vonulásáig tartotta.

12 KAJTÁR - SZEKERES, A tengerek és a hajózás jogtörténete kurzus vizsgaanyaga, passim.

${ }^{13}$ Ez úgy történt, hogy berendelt egyetemi dolgozószobájába, ahol fél óra alatt levizsgáztatott hadihajó-felismerésből a Breyer-féle Schlachtschiffe und Slacbtkereuzer 1905-1970 címú könyböl. Nehezítésként nem méretarányosan másolt elölnézeti vázrajzokat kellett felismernem és ismernem kellett néhány tengeri csata eseményeit is.
} 
publikáció létérôl is, ezek megszerzése pedig sok időbe és utánajárásba került, így számomra felbecsülhetetlen értékủ volt ez a segítség. Az 1990-es évek közepétôl indult levelezésünk, majd személyes találkozóink eredményeképp igen sok tengerészeti témáról eszmét cseréltünk. Néhány évvel a nyugállományba vonulása előtt tettük rendszeressé személyes találkozóinkat. Ezek témáit egy-egy évre előre megterveztük, saját anyagainkból felkészültünk, és ki-ki a saját kérdéséből előre kidolgozott vázlat alapján összegezte, mire jutott. Vizsgálódásainknak két fő iránya volt: egyes témák frissítése az időközben hozzáférhetôvé vált újabb adatok felhasználásával, továbbá a szakirodalomban túlnyomó többségben lévő álláspontok (példának okáért az ún. „all or nothing” felépítésű páncélzat megítélése) kritikai felülvizsgálata.

Emberi sorsok iránti érzékenysége miatt jellemző, hogy Kajtár István a legnagyobb irodalommal rendelkező és ezért legkönnyebben kutatható angolszász, illetve német hajózási témák mellett különös érdeklődéssel kutatta az orosz-szovjet flotta történetét. Talán nem véletlen, hogy első témába vágó publikációja is ezzel foglalkozik. Ennek során sok olyan epizódot gyūjtött össze, amelyek a hadigépezetek mellett az azon szolgáló emberek helytállását örökítik meg. Ma is emlékszem, milyen plasztikusan mutatta be a csuzimai csatában az orosz tengerészek, Szevasztopol ostrománál pedig a védők hősies magatartását. Sokszor ez az egyetlen esély, ami egy tengeri csatában a mûszaki, vagy éppen a mennyiségi hátrányt képes kiegyenlíteni - persze a véletlen szerencsén kívül. Másik érdekesség, hogy professzor úr a könyvekben találhatóknál nagyobb részletességû térképek megrajzolására is vállalkozott, hogy áttekinthetőbb és követhetőbb legyen egy-egy csata eseménysora. Az egyik első ilyen munka a csuzimai tengeri csata óriási méretű, kisebb szoba nagyságú méretpontos térképe volt, melynek részleteit még volt szerencsém látni.

Ebben az írásban a nyomtatásban megjelent írások, a levelezésünk és rendszeres beszélgetéseink felhasználásával kísérlem meg felvázolni Kajtár István hajózással kapcsolatos tevénységét, a magyar nyelven kiadott művein keresztül. ${ }^{14}$

\section{A tengerek jogtörténete}

\subsection{A hadihajókat eladják, ugye? ${ }^{15}$}

A badihajókat eladják, ugye? című újságcikk lendületesen, az átlag olvasók számára is jól követhetően vázolja fel a szovjet hadiflotta háromnegyed évszázados történetét. Érzékletes képekben ábrázolja a heroikus kezdetet, a matrózoknak a polgárháborúban játszott szerepét, ellenpontozva ezt a Kronstadtban kirobbant lázadással. Párhuzamot von a német és a szovjet diktátor irreális flottafejlesztési tervei ${ }^{16}$ között, jelzi mindkettejük csatahajók iránti vonzalmát. Összehasonlítja a tervezett hadihajók méretét a valóban megépültekkel, majd részletezi azoknak az óriáshajóknak a

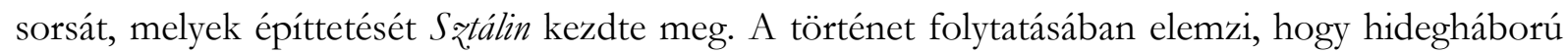
idején a szovjet flotta fejlesztésére milyen nagy hatással volt $S_{z}$ G. Gorskov tengernagy és ismerteti a létrejött óriási tengeri ütőerőt, de jelzi azt is, hogy ennek a hadigépezetnek a fenntartása

\footnotetext{
${ }^{14}$ Lásd továbbá német nyelven KAJTÁR, Der Schiffskommandant in der neuern Rechtsgeschichte.

${ }^{15}$ KAJTÁR, A hadihajókat eladják, ugye? 6.

${ }^{16}$ Hitlernél a Z terv, Sztálinnál az 1936-1945 közötti első flottafejlesztési program.
} 
felemésztette a birodalom erejét. ${ }^{17}$ „S mi várható most?” - teszi fel a kérdést, melyre válaszul jövendöli, hogy a hajók egy részét majd eladják, másokat felosztanak maguk között az örökösök, a maradék pedig a kikötőkben fog elrozsdásodni. Ezek jórészt már meg is történtek: idegen kézbe került a flotta négy nagy helikopter-hordozó cirkálója (Kijev, Mins₹̨k, Novorosszijk, Baku), és a kínaiak hosszú évek fejlesztését spórolták meg a Varjag repülőgép-hordozó anyagárban történt megszerzésével. A flotta egykori ökle, a ballisztikus rakétákat hordozó tengeralattjárók tömege - az atommeghajtás miatt - környezetszennyező időzített bombaként rozsdásodik többek között Poliarníj, Vidjajevo kikötőjében.

Ám az egykori szovjet flotta nem tűnt el nyomtalanul. A szerző a fenti saját kérdésére adott válaszában van egy, az előrelátó jogtörténészhez illő feltétel, hogy tudniillik akkor lesz ez a szovjet hadiflotta sorsa, „ha nem jön egy erós cár’. Nos, jött a kellően erőskezű vezető és a - most már nem szovjetnek nevezett - flotta új erőre kapott: új atomhajtású rakétahordozó tengeralattjárók, ${ }^{18}$ új vadász tengeralattjárók ${ }^{19}$ épültek, az egykor Jurij Andropov néven szolgáló szovjet nukleáris meghajtású csatacirkáló immár Pjotr Velikij néven vezeti a FÁK flottáját, sőt tervezés alatt áll az új, atommeghajtású, teljes fedélzetû repülőgép-hordozó (tervszám: Project 23000 Storm) is.

Az írás a szerző előadásaira jellemzően különleges epizódokkal (Kuznyecov admirális halvány ellenkezése az erôltetett flottafejlesztéssel kapcsolatban, a hamis győzelmi jelentések, Hruscsov látogatásának elmaradása az amerikai repülőgép-anyahajón stb.) tartja fenn az érdeklődést egy olyan témában, ami az átlagos újságolvasót valószínűleg nem érdekelné.

\subsection{Az Alabama-ügy ${ }^{20}$}

A CSS Alabama egy Angliában, 1862. május 15-én vízre bocsátott bark volt, mely az 1861-1865 között lezajlott UsA-beli polgárháborúban az Amerikai Konföderációs Államok érdekében az Unió hajói ellen portyázó hadjáratot folytatott. Csaknem két év alatt 71 északi hajót zsákmányolt és akkori értéken mintegy hatmillió dolláros kárt okozott ellenfelének. Múködése az UsA és NagyBritannia között jogvitát okozott, melyet végül 1872 szeptemberében zárt le a Genfben ülésező nemzetközi választottbíróság. Ezt a történetet dolgozza fel Kajtár István 1997-ben megjelent tanulmánya.

A déli hajó azzal szított vitát, hogy egy semleges állam, Nagy-Britannia kikötőjében építették, ráadásul angol legénység mûködtette, akik viszont egyenruhás déli tengerésztisztek irányítása alatt egy másik hadban álló állam hajói ellen harci cselekményeket hajtottak végre a világ tengerein. Az írás a polgárháború rövid bemutatását követően először a déliek elleni tengeri blokádot és a blokádtörő hajók tevékenységét taglalja, körvonalazva azokat a körülményeket,

\footnotetext{
${ }^{17}$ Köszönhetően Ronald Reagan elnök fegyverkezési programjainak, például a Stratégiai Védelmi Kezdeményezésnek (SDI, a sajtóban: csillagháborús terv) és az ún. 600 hajós programnak.

${ }^{18}$ Ezt Borej osztálynak nevezik, melynek első hajóját (Jurij Dolgorukij) 2008 februárjában bocsátották vízre. Lásd SZABÓ, Az orosz Borej tengeralattjáró hajóosztály 63.

${ }^{19}$ Akula-II osztály, 971-971M típus. Lásd SZABÓ, A 971 típusú, atomhajtású vadász-tengeralattjáró 37.

${ }^{20}$ KAJTÁR, Css Alabama 14-20.
} 
melyek az Alabama és társai ${ }^{21}$ megépítéséhez vezettek. A jegyzetben az Alabama későbbi kapitányának, Raphael Semmesnek az életútját is ismerteti, majd ismerteti a hajó megépítésének és felszerelésének kalandregénybe illő történetét. Az Alabama sorsa jelzi azokat a nehézségeket, melyekkel a portyázó hadviselés jár: az utánpótlás óriási nehézségeit, a múködési terület folyamatos változtatásának kényszerét, a zsákmányolt hajók legénységének elhelyezését és a semleges államok kikötőinek használatát. Ilyen körülmények között - hasonlóan a legtöbb portyázó hajóhoz ${ }^{22}-\mathrm{a}$ déliek hajója se kerülhette el sorsát: az északi Kearsarge a Cherbourgból kihajózó, a hosszú bevetésben lecsökkent harcértékű Alabamát elsüllyesztette. A cikk természetesen nem nélkülözi a szerzô munkáira oly jellemző kulturtörténeti jellegû érdekességeket: az Alabama lobogójának sorsa, a kapitány és a hajóorvos emlékezetes tettei ${ }^{23}$ mellett az amerikai haditengerészet azon gyakorlata is érdekes, hogy a győztes Kearsarge nevét azóta is mindig viseli az amerikai hadiflotta egy hadihajója. Az összegzés kitér a portyázók eredményeire, majd részletezi a jogvita történetét és megoldását. Igen részletesen bemutatja a kereskedelmi hajók elleni tevékenység jogi megítélését, a közönséges tengeri rablók és a korzárok közötti különbséget, valamint az ún. hivatalos kalózlevelek alapján tevékenykedő hajósok zsákmányának sorsát. A téma aktualitását a két világháborúban munkálkodó portyázók, valamint a napjainkban is létező kalózkodás adja.

\subsection{A tengeri kaméleonok ${ }^{24}$}

Sokak szerint a háború elsősorban szállítási és ellátási probléma. Ezért a tengeri szállítási útvonalakon közlekedő kereskedelmi hajók elleni ún. cirkáló hadviselést az első világháborúban is alkalmazták. Így vált híressé többek között a Seeadler vagy a Möwe segédcirkáló neve és tevékenysége.

A második világháborúban a német oldalról komoly felszíni hajóegységek (nehézcirkálók, sőt csatacirkálók, mint Admiral Graf Spee, Admiral Hipper, Scharnhorst, Gneisenau) mellett jó néhány német segédcirkáló - azaz felfegyverzett gyorsjáratú kereskedelmi hajó - is támadta a szövetségesek tengeri szállítási útvonalait; ezek olykor kalandregénybe illő történetéről szól a szerző következő tanulmánya. Ezen hajók, mint a cikkben említett Atlantis, Komet, Kormoran, Orion, Pinguin, Thor, Widder, Coronel, Michel és Stier, tevékenységük során sokszor nem tartották be a portyázó hadviselés szabályait, hiszen magukat semleges állam lobogójával álcázva, sőt más hajó külsejét imitálva igyekeztek elkerülni a felderítésüket. Erre nagy szükségük is volt, hiszen kijelölt mûveleti területeik a hazájuktól rendkívül messze - a Csendes-óceánon, az Indiai-óceánon és az Atlanti-óceán déli vizein - voltak. Kapitányaiknak az alapvetően ellenséges körülmények között (teljességgel magukra utaltan, az ellenség által uralt vizeken, a segítségnyújtás reménye nélkül) nagyon nehéz volt mind a feladat végrehajtása, mind pedig az utánpótlás (víz, élelmiszer, lőszer,

\footnotetext{
${ }^{21}$ Liverpool kikötőjében James D. Bullock további négy hajót építtetett, melyek szintén eredményesek voltak. Ilyen volt többek között a Florida és a Shenandoah.

${ }^{22}$ A cirkáló hadviselést folytató hajók legnagyobb része előbb-utóbb a tenger fenekén végezte, persze csak akkor, ha a süllyedés helyén elég mély volt a víz. Az Admiral Graf Spee német nehézcirkálónak (akkori hírlapi megnevezésével zsebcsatahajónak) a Montevideoi-öbölben lévő roncsa sokáig látható volt.

${ }^{23}$ A kapitány a süllyedő hajóról a tengerbe veti a kardját, a hajóorvos a sebesültek ellátása miatt nem hagyta el a hajót, majd vele merült el.

${ }^{24}$ KAJTÁR, Német segédcirkálók a második világháborúban 82-83.
} 
karbantartáshoz szükséges anyagok) biztosítása. A rettenetesen hosszún ${ }^{25}$ bevetéseket, az állandó készenlétet, a kiszolgáltatott helyzetet a legénység számára a más hajókon ismeretlen lehetôségek: könyvtár, mozi, illetve az ún. fedélzeti szabadságolás tették elviselhetőbbé. A tevékenységükről elmondható, hogy jelentősen több hajóteret süllyesztettek el, mint a bevetett felszíni hadihajók: az Admiral Graf Spee nehézcirkáló 50.000 BRT-s teljesítménye harmada a Pinguin (155.000 BRT) vagy az Atlantis 146.000 BRT-s eredményének. Viszont egyértelmű, hogy a kereskedelmi hajók elleni „tonnaháborút” legnagyobb részben a német tengeralattjáró-flotta vívta meg és a felszíni flotta ehhez csak segítséget nyújtott, hiszen csak a tíz legeredményesebb német búvárhajó összesen 1.870.000 BRT hajóteret süllyesztett el. A német segédcirkálók a távoli vizeken remek tengerészszakmai teljesítményt nyújtottak és harci szellemüket sem érheti kritika. Előfordult, hogy a sokszorta erősebb hadihajóval szemben is eredményesen vették fel a harcot. ${ }^{26}$

Ami a segédcirkálók jogi megítélését illeti, az 1907-es hágai (VII.) egyezmény szabályozta a kereskedelmi hajók hadihajóvá történő átalakítását. Előírta a hajón a hadijelvények viselését, a kapitánynak kötelezően a haditengerészet tiszti névsorában kellett szerepelnie, a legénységnek katonai fegyelem alatt állnia, a hajónak szerepelnie kellett a hadiflotta jegyzékében és tevékenységében vonatkoztak rá a haditörvények és hadiszokások. A segédcirkálók tevékenységük során a fenti szabályokat nem mindig tartották be. Problémás volt az előzetes figyelmeztetés kérdése, az idegen lobogó használata, az álcázás és a hadifoglyokkal való bánásmód is; hangsúlyozni kell azonban, hogy ezek a problémák nem csak a német, hanem a többi, segédcirkálókat alkalmazó hadiflottánál is felmerültek, hogy az álcázott angol Q-hajóknak a kifejezetten a megtévesztésre alapozott tevékenységéről ne is beszéljünk.

\subsection{A tengeri zsákmányjogró $1^{27}$}

A tengeri zsákmányjogról írt tanulmány az Alabama-ügyben felvetett egyes kérdések részletesebb vizsgálatát és az ebből levont általános következtetéseket tartalmazza. Elsőként igen érdekesen pontosítja a zsákmány kifejezést. A szerző megkülönbözteti egyrészt a hadiflotta által a hadi tevékenység során megszerzett javakat (fegyverek, hajók), valamint a tengeri jövedelemszerző magántevékenység, azaz a tengeri rablás eredményét, amit prédának nevez. A tanulmány vizsgálatának célkeresztjében a tengeri tevékenységnek az előbbi két végpont közé eső tevékenysége áll. A zsákmány tehát az, amit vagy hadihajó ejt, vagy olyan személy, akit egy állam hivatalos pátenssel erre felhatalmaz. A modern tengeri háborúkban ezt a fajta hadviselést cirkálóháborúnak nevezik, melyet a zsákmányjog szabályai szerint viselnek.

A középkorban már születtek zsákmányjogi jellegű szabályok: a tanulmány bemutatja a Barcelonában a 15. században keletkezett Consolato del mare részletesnek tekinthető zsákmányjogi szabályzását, valamint XVI. Lajos 1681. évi nagy ordonnance-ának témába vágó rendelkezéseit. A krími háborút lezáró párizsi nemzetközi konferencián született egy, a tengeri háborúk jogára

\footnotetext{
25 Az Orion 510, az Atlantis 516, a Komet 622 napos bevetést teljesített.

${ }^{26}$ A Kormoran a nála sokkal erősebb ausztrál Sidney cirkáló ellen vette fel a tények alapján reménytelen harcot, végül a két hajó együtt merült a hullámsírba.

${ }^{27}$ KAJTÁR, A tengeri zsákmányjogról 7-14.
} 
vonatkozó deklaráció (1856. április 16.) is. Ez kimondta a pátenses kalózkodás és a semleges áru elkobzásának tilalmát, a 4. pont pedig a tengeri blokád (tengeri zárlat) szabályait fektette le. Ez a deklaráció tehát a hadihajók számára továbbra is megengedte a zsákmányolást, ezért a későbbiekben az Egyesült Államok nem csatlakozott a deklaráció ezt kimondó első pontjához. ${ }^{28} \mathrm{~A}$ 19. században mozgalom indult a hadihajók zsákmányjogának eltörlésére, de erre nem került sor éppúgy, mint az 1909-es londoni tengeri jogi konferencia zsákmányjogra is kiterjedô egyezménytervezetének ratifikálására. A hágai egyezményekére viszont igen, valamint született két, a tengeralattjárók magatartására vonatkozó egyezmény is. A nemzetközi zsákmánybíróság felállítása azonban továbbra is elmaradt.

A tanulmány a továbbiakban részletesen bemutatja a tengeri zsákmányolási manőver egyes részeit: a kereskedelmi hajó megállításának részleteit, bizonyos feltételek fennállta esetén annak átvizsgálását, hadi dugáru fellelése esetén a hajó lefoglalását és annak saját, vagy szövetséges kikötőbe való bejuttatását. A kikötőbe kísért kereskedelmi hajó és rakománya sorsáról aztán a zsákmánybíróság jogosult dönteni. Az Osztrák-Magyar Monarchiában sor került zsákmánybírósági rendtartás megalkotására, melyet Tis a István magyar királyi miniszterelnök az 1914. évi 8.704. M.E. számú rendeletével hirdetett ki. A tanulmány ezt a rendtartást teljes egészében közli és nem marad adós annak kritikájával sem: az elfogott hajó hiányos jogai, a formalizált bizonyítás, az egész eljárás merev és bürokratikus volta. Ezek az eljárási szabályok igencsak elmaradnak a 20. században már magas színvonalú általános perjogi szabályainktól. Az elmélet és a jogszabályi környezet prezentálása után még érdekesebb annak bemutatása, milyen is volt a tengeri zsákmányolás gyakorlata 1914 és 1918 között az Adrián, valamint a modern tengeri háborúkban; mindezek különkülön fejezetben szerepelnek a tanulmányban. Az összefoglalásban a tengeri zsákmányolás nagyívű áttekintését olvashatjuk, melynek konklúziója: a tengeri hadviselés megváltozásával a tengeri zsákmányjog háttérbe szorult. Ez a tanulmány is bőségesen tartalmaz olyan részleteket, melyek alkalmasak a laikus olvasó érdeklődésének felkeltésére: ilyen többek között a kereskedelmi hajó megállításának és átvizsgálásának koreográfiája, vagy a korzárok egy nagy fogásának bemutatása. A jogtörténeti bemutatót itt is kiegészíti a kultúrtörténeti kitekintés: hogyan birkózott meg a magyar terminológia a maritim szakkifejezésekkel.

\subsection{A Mediterránum tengeri joga ${ }^{29}$}

Kajtár István időrendben következőként megjelent tanulmánya két egymással összefüggő témát vizsgál: a kalózkodást és a tengerjogi szabályzást. Az emberi közösség ellenségei alcímű bevezető részben a szerző számos érdekes példát hoz fel a Földközi-tengeri kalózkodás történetéből. A Iulius Caesart is foglyul ejtő - majd ezért életükkel fizető - tengeri rablók történetével kezdve mutatja be a Mediterráneum kalózainak működését, egészen a lepantoi tengeri csatáig, ahol a barbareszk hajósok igen jelentős szerepet játszottak a török hajóhad harcában. Felhívja a figyelmet a pátenssel rendelkező korzárok és a közönséges tengeri rablók közötti jelentős különbségre és a magyar nyelv

\footnotetext{
${ }^{28}$ Ezt később, a polgárháború hatására szívesen pótolták volna, a CSS Alabama és társai tevékenysége miatt főleg a déli portyázó hajók.

${ }^{29}$ KAJTÁR, A Mediterráneum tengerjogának történetéhez 71-77.
} 
műszavainak azon hiányára, hogy az előbbi két kategória tevékenységén felül még a tengeralattjárók és a segédcirkálók kereskedelmi hajók elleni műveleteit is kalózkodás megjelöléssel illetik.

A tanulmány ezt követően bemutatja és értékeli Mária Terézia 1774-ben, Bécsben kiadott Editto politico di navigazione mercantile címú hajózással foglalkozó ediktumát és közli annak tizenhat, különböző részletkérdésekre vonatkozó toldalékát, többek között a különféle címen fizetendő taksákról, a hajós legények lajstromáról, vagy az idegen kikötőkben időző hajóskapitányoknak a helyi szabályok megszegésének tilalmáról. A toldalékok között az edictum 1804-es magyar kiadásában már szerepel a török császár ausztriai zászlóval utazó hajóknak kiadott Firmanója (firánja, azaz a szultán kézjegyével ellátott dekrétuma), melynek részletes, szöveghű közzételével, majd elemzésével folytatódik a tanulmány. A szerző szerét ejti, hogy a két forrásnak a kalózkodással kapcsolatos egyes részleteit bemutassa ${ }^{30}$ és külön részben megemlékezzék Peter Philiph HerbertRatkal osztrák bárónak, konstantinápolyi nagykövetnek az osztrák kereskedelmi hajózás biztosítása érdekében kifejtett tevékenységéról. A záró rész első felében áttekintést kapunk az osztrák császárikirályi haditengerészetnek a kalózokkal szembeni tevékenységéről és a foglyok kiváltására alakult szerzetesrendekről. A befejezés a kalózkodás új távlatairól, az ellene való küzdelem egyes jogi eszközeiről (többek között a biztosításról) szól, melynek aktualitása sajnos napjainkban is fennáll. ${ }^{31}$

\subsection{A magyar tengerjog matuzsálemei ${ }^{32}$}

A magyar tengerjogi szabályzásról szóló tanulmányában a szerző nagy részletességgel elemzi a Mária Terézia által 1774-ben, Bécsben kiadott Editto politico di navigazione mercantile címü, hajózással foglalkozó ediktumot, mivel erre a magyar királyi kereskedelemügyi miniszter 1926. évi 94.602. sz. rendelete (mely a kereskedelmi hajók személyzetének szolgálati viszonyaiban érvényes jogszabályokról szól) úgy hivatkozik, mint akkor is hatályos jogszabályra.

Ennek az elemzésnek az az alapja, hogy az ediktum jogszabályi minősége, a kötelezettségek megfogalmazása és a szankciók is archaikusak, emiatt az ediktum modern jogtechnikai módszerekkel nem mérhető. A jogi kultúrtörténet eszközeivel viszont igen, így rendkívül érdekes a tanulmánynak a császárnő és királynő anyáskodó gondoskodását, a szabályzás morális jellegét vagy éppen a vallási jellegű parancsokat bemutató része is. A másik alapvető, magyar tengerjogban is alkalmazandó norma a Code Commerce II. hajózással foglalkozó része (190-436. cikkely) volt. Ennek 1808-ban Codice di Commercio di terra e mare címen kiadott olasz nyelvú szövege még hosszú ideig ${ }^{33}$ használatos volt a joggyakorlatban.

A 19. század végén a tengerjog fő intézményei már igen bonyolulttáa ${ }^{34}$ váltak, felmerült az igény a modern és átfogó szabályzásra. Ez a törekvés azonban eredménytelen maradt; ennek fő

\footnotetext{
30 Például a 23. \ tiltja, hogy osztrák alattvaló fegyveres hajót rablás, vagy hadakozás végett (...) felkészítsen, vagy kormányozzon (...) kivéve, ha erre engedélyt (pátenst) kapna!

31 A kalózkodás témája ma is aktuális. A kalózok által váltságdíjként kért és hozzájuk befolyt összegeket évi 100-200 millió US dollárra becsülik, lásd MARSAI, Szomália és kalózai 16.

${ }^{32}$ KAJTÁR, A magyar tengerjog matuzsálemei 225-245.

33 A mủ hatása túlélte a francia uralmat, szabályai szokásjoggá váltak, hatása még 1945 után is fennmaradt.

${ }^{34} \mathrm{~A}$ tengeri jog fő intézményeit a szerző a hajóskapitányok vizsgaanyagának részletes ismertetésével illusztrálja. Ez négy nagy kérdéscsoportban összesen 60, önmagában is bonyolult kérdéskört tartalmaz, a kapitányoknak tehát igen felkészültnek kellett lenniük!
} 
oka, hogy az 1867-es osztrák-magyar közjogi kiegyezés a kereskedelmi hajózás és annak szabályzása ügyeit a közös egyetértéssel intézendő ügyek közé sorolta. Mivel az osztrákok a német tengerészeti rendtartást, a magyarok viszont a mediterrán (olasz-francia) tengerjogi megoldásokat tekintették modellnek, megegyezés - és így az egységes szabályozás - nem jött létre, bár a tengerészeti rendtartásról szóló 1896. XI. 13-i javaslatot a képviselőház harmadik olvasatban is elfogadta. Ezen az áldatlan helyzeten végül az 1908. évi XII. törvénycikkbe iktatott vám- és kereskedelmi szerződés változtatott, hiszen ez nem írta elő azt, hogy a két államterület tengerpartjain azonos tengerjogot kellene alkalmazni. Sajnos nem jött létre a magyar tengeri magánjog kodifikációja sem: az 1894-ben Nagy Ferenc ${ }^{35}$ által készített tengeri magánjogi törvénykönyv egyeztetése elhúzódott, megegyezés nem született. 1908-ban a szabályzás nemzeti hatáskörbe kerülését követően Nagy Ferenc új tervezetet készített, de ennek életbe léptetése is elmaradt. Ironikus, hogy a magyar kereskedelmi hajók személyzetének szolgálati rendtartásáról szóló jogszabály (1934. évi XIX. tc.) egy olyan országban született, amelytől Trianon elvette a tengerpartját. A tengeri hajózás lehetősége azonban a Dunán keresztül még nyitva állt. A szabályozás frissítése sajnos nem túl aktuális, hiszen a magyar kereskedelmi hajózás a MAHART utolsó kereskedelmi hajójának (Vörösmarty) lobogó-bevonásával 2000 októberében megszűnt.

\subsection{A császári és királyi haditengerészet jelképei ${ }^{36}$}

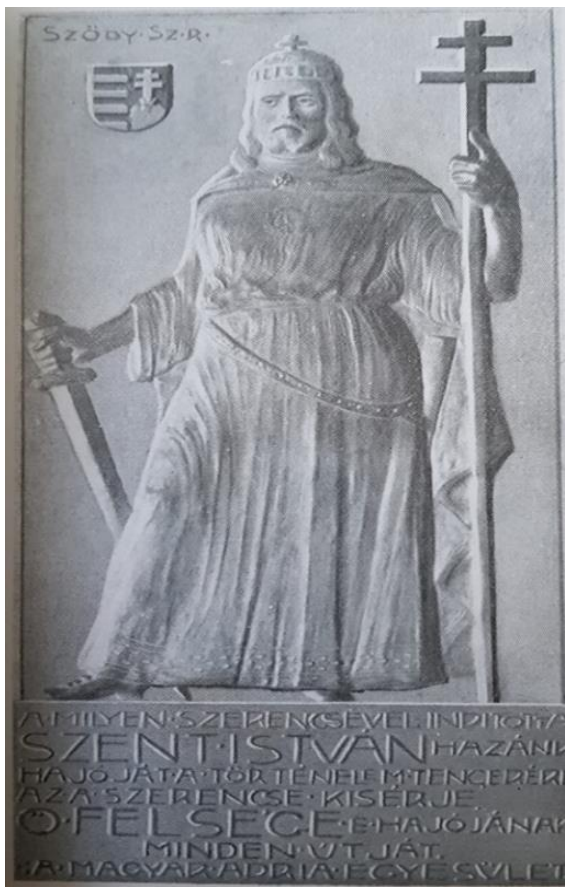

Egy 1994-ben megjelent tanulmányában Kajtár István már említi egy hatalmi jelkép, a sas kapcsolatát a hadihajókkal. A haditengerészeti jelképekről szóló munkájában ${ }^{37}$ az akkor megkezdett kutatási irányban elért újabb eredményeit mutatta be, ezúttal az osztrák-magyar monarchia haditengerészetének jelképeire összpontosított. Első témája a hajók névadása, melyben az általánosnak tekinthetô okokról szól, mint a dinasztikus okból adott (Habsburg, Erz̧herzog Ferdinand Max) nevek, a dicsőséges hadvezérek nevei (Prinz Eurgen, Don Juan D'Austria) és mesebeli állatok nevei (Drache, Salamander), majd egy sajátos, a kettős monarchia létéből következő dualista névadási szempontról is említést tesz. Így az azonos hadihajóosztályba tartozó hajók nevei közül egynek magyar lett a neve, például Budapest vagy Árpád, bár a konkrét nevek kiválasztása sokszor igen nehézkes volt. ${ }^{38}$

2. kép: A Szent István-plakett ${ }^{39}$

\footnotetext{
35 Nagy Ferenc szakmai életrajzát a tanulmány 13. pontja tartalmazza.

${ }^{36}$ KAJTÁR, Egy hatalmi jelkép kultúrtörténeti gyökerei 11-17.

${ }^{37}$ KAJTÁR, A császári és királyi haditengerészet jelképei 184-188.

${ }^{38}$ A Viribus Unitis csatahajóosztály negyedik tagjának nevéül javasoltakat (Hunyadi, Corvin Mátyás, Eržsébet királynê) Ferenc Ferdinánd trónörökös sorban elutasította, így lett végül e hajó neve Szent István.

${ }^{39}$ Forrás: BALOGH - CSEPREGI, A Szent István csatahajó és a csatahajók rövid története 175.
} 
A tanulmány a következőkben bemutatja a lobogókat és a címereket, közte a Szent István csatahajóhoz kapcsolódó jelképeket (ereklye-zászló, bronzplakett) is. Megindító az osztrák-magyar flotta 1918 októberében történt átadása keretében magának az átadási ceremóniának, benne a lobogó levonásának részletes leírása. Ennek során a vezérhajón (Viribus Unitis) Horthy Miklós aznap még - ellentengernagy a Délszláv Tanács illetve Method Koch szemtelen, azonnali lobogóváltás iránti követelése ellenére ragaszkodott ahhoz, hogy amíg ő a fedélzeten van, addig a tengernagyi és a piros-fehér-piros hadilobogó is fenn maradjon az árbocon. A kormányzó hivatali ideje alatt állított Haditengerészeti Hősi Emlékmű részletes bemutatását egy kuriózum követi: annak leírása, hogyan került egy osztrák-magyar hadihajó lobogója egy, a második világháborúban szolgáló és azt túlélő ${ }^{40}$ német nehézcirkálóra. Ez a remek tanulmány később a Magyar Hadtudományi Társaság által szervezett Hadtörténeti esték címû sorozat előadásaiból szerkesztett könyvben is napvilágot látott. ${ }^{41}$

\subsection{Hajónevek a tengeri hatalom szimbólumrendszerében ${ }^{42}$}

A tanulmány egy korábban német nyelven megjelent munka ${ }^{43}$ magyar nyelvű változata. A szerző az általa vizsgált hatalmi szimbólumok felidézésétől vezet át a hajózással kapcsolatos motívumok, például a római forum rostruma említéséig. Számos példát hoz fel a hajókon elhelyezett hatalmi jelvényekre (címerek, kitüntetések, a nagy japán hadihajók orrán díszlő krizantém).

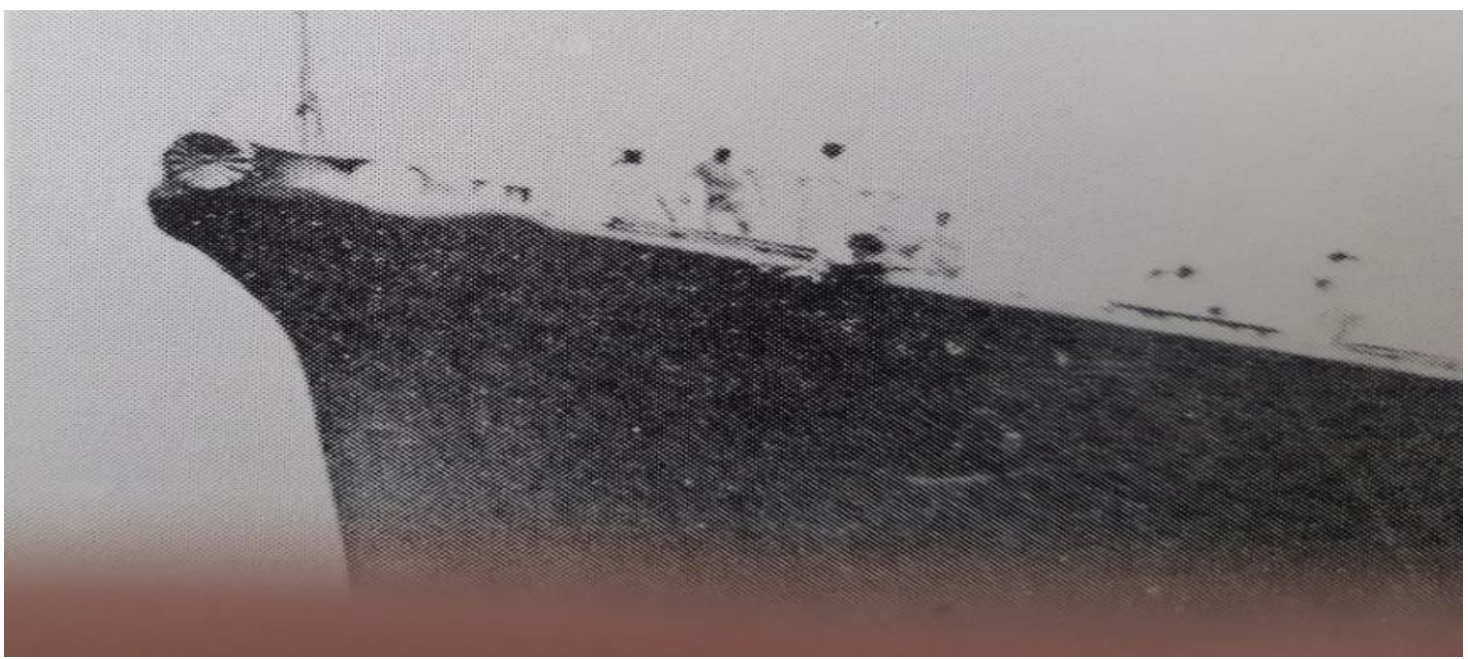

3. kép: A krizantém a Su₹uya japán nehézcirkáló orrán ${ }^{44}$

\footnotetext{
40 A Prinz. Eugen német nehézcirkáló annak ellenére, hogy a Bismarck csatahajó társaként a veszélyes ún. Rheinübung műveletben is részt vett, mely a Hood brit csatacirkáló elsüllyesztését eredményezte, túlélte a világháborút. A hajó amerikai kézbe került, akik a Bikini-atollnál végzett atomkisérletekben teszthajóként használták fel. Két atombomba robbanását követően a még úszóképes hajót átvontatták a Kwajalein-atollhoz, ahol javítás hiányában hónapokkal később a sekély vízben felborult és elsüllyedt. A cirkáló egyik hajócsavarját 1978-ban leszerelték és Németországban, a laboei Német Tengerészeti Emlékhelyen kiállították.

${ }^{41}$ KAJTÁR, Az osztrák-magyar haditengerészet jelképeiről 83-96.

${ }^{42}$ KAJTÁR, Hadihajónevek a tengeri hatalom szimbólumrendszerében 255-267.

${ }^{43}$ KAJTÁr, Machtsymbole auf der See 46-67.

${ }^{44}$ Forrás: JENTSCHURA - JUNG - MiCKEL, Warships of the Imperial Japanese Navy 86.
} 
Az írás gerincét a hadihajók elnevezésének elemzése képezi. A bevezető rész az elnevezések leggyakoribb eseteit (mitológiai szereplők, tulajdonságok, történelmi személyiségek, csaták és egyéb földrajzi nevek) összegzi, majd bemutatja a hajó-keresztelés ceremóniáját. Egy-egy hajó neve változhat is eladás vagy bérbeadás esetén, de a zsákmányolt egységeknél is fő szabályként új neve lesz a járműnek - persze, mindig van kivétel (Retvizan). Érdekes az 1914-es flottazsebkönyv szerint kimutatott legnépszerúbb hajónevek ${ }^{45}$ sora.

A továbbiakban a szerző nemzetenként gyüjti össze a jellemző névadási szokásokat, precíz statisztikákkal. Érdekesnek tartom, hogy a hagyományosabb neveken túl előfordul a hősi halottak elôtti tisztelgés (az olasz Comandanti Medaglie d’Oro rombolóosztály ${ }^{46}$ nevei), illetve a japán névadási szokások, ahol a hadihajók nem viselik sem az uralkodó, sem katonák, vagy államférfiak neveit, hiszen az egyén csak a kötelességét teljesíti. Így ott a földrajzi neveken túl kifejezetten költői elnevezéseket (Shokaku, azaz Szármyaló daru, vagy Akebono, azaz Hajnalpír) is lehet találni. A tanulmány az egyes hajókhoz a tengerészek szóhasználatában kapcsolódó nevek érdekességeivel zárul: így például az Oldenburg páncéloshajó a rossz tengerállósága miatt kapta a Vasaló (gúny)nevet.

\subsection{Az antic görögök tengeri háborúi ${ }^{47}$}

Merőben másról szól a szerző nyomtatásban megjelent következő tanulmánya. Ebben a történeti bevezető után röviden összefoglalja a kor leghíresebb, a görögök részvételével lezajlott tengeri csatáit: a harmadik perzsa háború részeként a szalamiszi görög diadalt; az Athén vereségét hozó négy szyrakuszai tengeri csatát; az arginusziai és az Athén végső vereségét elhozó aioszpotamoi összecsapást. A száraz történelmi tényeken túl az írás tartalmazza a trierák és a pentekonterák technikai jellemzőit, megemlékezik legénységükről és vezetésükről is; a csatában a perzsa ellenfelet döfőorrával elsüllyesztő görög hajó leírásának mikrorealizmusa átérezhető emberi valósággá teszi a régmúlt eseményt. A tanulmány kultúrtörténeti apropója a bübrisz vizsgálata, melyet nemcsak etikai, de tágabban értelmezve politikai fogalomként is vizsgál és a görög tengeri háborúk eseményeivel illusztrál.

\subsection{A lepantói csata ${ }^{48}$}

Vannak hatásukban olyan tengeri csaták, melyek jelentőségük miatt az ezzel foglalkozók számára megkerülhetetlenek. Az 1571. október hetedikén megvívott lepantoi csata is ezek közé tartozik, melyről Kajtár István hosszú és igen értékes tanulmányt jelentetett meg.

\footnotetext{
${ }^{45}$ Ezeket a 3. oldal 7. pontja sorolja fel.

${ }^{46}$ A tervezett 20 hajó közül csak 9 db építését kezdték meg és egyetlenegyet, a Commandante Margottini nevút bocsátották vízre, de egyiket sem fejezték be. Szerencsére más tengerészek nevét viszont elkészült és hadrendbe állított hajók őrzik. Ilyen például az USS Juneau cirkálón meghalt öt testvér nevét megörökítő USS The Sullivans: Ezt a Flecher osztályú rombolót Buffalo kikötőjében múzeumhajóként ma is meg lehet tekinteni.

${ }^{47}$ KAJTÁR, Az antik görögök tengeri háborúi a Kr. e. V. században 182-187.

${ }^{48}$ KAJTÁR, Lepanto 139-162.
} 
A Földközi-tengeri stratégiai helyzet, valamint a kor hadihajói típusainak (a gályák és galeasszok) bemutatása után a csata létrejöttének két fontos körülményét tárgyalja: Ciprus török kézre kerülését, benne Famagusta védelme vezetőjének (Marc-Antonio Bragadino) tragikus sorsát és a Szent Liga megalakulását. A történeti előzmények után a résztvevôk számbavétele következik: elképesztő erők feszültek egymásnak, összesen több, mint $400^{49}$ hadihajó. Micsoda látvány lehetett ez a két flotta! A hajók persze csak eszközök, ezért alapvető jelentőségű a hadvezérek szerepe. A Liga oldaláról Don Juan d'Austria föparancsnokon kívül a velencei kontingenst vezetô Sebastiano Ventier, valamint a tartalék vezére, Santa Cruz márki személyét mutatja be a tanulmány. A törököknél hátrányt jelentett, hogy fővezérüknek, Müezæinzzade Ali kapudán pasának nem voltak tengeri harci tapasztalatai. Bővében volt viszont ezeknek a török balszárny vezetôje, Uluch Ali algíri beglerbég, melyekre a több évtizednyi, a korzár vezérek (Chair ad Din, Turgut) mellett a barbareszk hadjáratokban való részvételével tett szert. Ez a regényes életű, tehetséges tengerész már a csata után három héttel - a fővezér halálát követően - a török flotta vezetőjévé vált. A vezéreken kívül természetesen a legénység szerepe is lényeges: sokat nyomott a latban az a tény, hogy a törökök a csata előtt zsákmányoló bevetésen vettek részt és fáradtan kezdték az összecsapást. A Liga hajóin sem volt minden rendben: a véres következményekkel járó fegyelmezetlenség felelőseit a velencei tengernagy azonal kivégeztette. Érdekes, hogy mindkét félnél a csata előtti utolsó haditanácson többen javasolták az ütközet elkerülését, de a fővezérek ellentétesen döntöttek. A csata eseményeit a tanulmány három részre (a török jobbszárny megkerülő manővere és felmorzsolódása, a centrum harctevékenységei, a török balszárny sikeres manőverezése) bontva mutatja be. A török flotta pusztulását azonban a kereszténység nem tudta kihasználni - összegez a szerző. A rá jellemző érzékletesség, emberi epizódok, érdekességek felvillantása lehetôvé teszi, hogy ez az írás is folyamatosan fenntartja a laikusok érdeklődését is. Ennek jelentőségét a tudományos igényü munkáknál nem lehet eléggé hangsúlyozni. Természetesen Kajtár István, mint a jogi kultúrtörténet egyik magyar úttörője, itt is szerét ejti röviden jelezni a csata emlékezetének a hadihajó-nevekben, dalokban és képzőművészeti alkotásokban való továbbélését.

\subsection{A tengeralattjárókró $1^{50}$}

A tengeralattjárók talán a legkülönlegesebb hadihajók. A mélybe merülés képessége, az ebből eredő rendkívüli veszély ${ }^{51}$ és az egymásra utaltság által kialakított különleges bajtársiasság, a rejtve hajózás, a meglepetésszerű támadás lehetôsége sok könyvet és filmet ihletett. A hollywoodi mesék közül üdítő kivétel a Das $B o o t^{2}$ című film, mely más, reálisabb szemszögből közelít a tengeralattjárósok

\footnotetext{
${ }^{49}$ A csatában részt vett hajók számáról megoszlanak a vélemények: némelyek a törököknek több mint 220, a Ligának 200 gályát tulajdonítanak, míg mások álláspontja szerint a törökök 220 gályája harcolt a Liga 206 gályája és 6 galeassza ellen. Lásd GULAS - LESCINSKY, A vitorlás hajók története 47.; PEMSEL, Seeherrschaft I. 151.

${ }^{50}$ KAJTÁR, Tengeralattjárók 217-232.

51 Gondoljunk csak a második világháború német tengeralattjáró-személyzetének elképesztően magas, 70\%-ot is elérő halálozási arányára.

${ }^{52}$ Az 1981-ben készült filmet Wolfgang Petersen írta Lothar-Günter Buchheim regénye alapján, Wolfgang Petersen rendezte, a főszerepet pedig Jürgen Prochnow játszotta.
} 
történetéhez. Éppen ilyen, az átlagtól eltérő szemlélet tükröződik a következőkben ismertetendő tanulmányban is.

Szívszorító leírni, de a Tengeralattjárók. Benedek Ferenc professzor emlékének ajánlva című tanulmány a hajózás témakörében az utolsó Kajtár István nyomtatásban megjelent munkái közül. Ennek bevezető részében a tengeralattjárók történetének a modern állam- és jogtörténethez való kapcsolódását jelzi, majd néhány fontosabb személyéhez (David Bushnell, Robert Fulton, Wilhelm Bauer, Georg E. Dixon, Dupuy de Lome, Gustav Zédê) kapcsolódva röviden ismerteti a fejlesztés lépcsőfokait. Az első világháborúban történt, a jogtörténet számára is témát nyújtó ügyek (a Lusitania-ügy és a Baralong-ügy, valamint Fryatt kapitány ügye) bemutatását követően részletesen bemutatja a tengeralattjárók eljárásának jogi szabályzására vonatkozó kísérletet, azaz az 1936-os londoni jegyzőkönyv szabályait. A kísérlet mint kifejezés használatának indokoltságát jelzik a második világháborúban megtörtént, a tanulmányban közölt esetek (az Athenia, a Laconia, a Peleus és a Wilhelm Gustloff hajók történetei) hiszen ezek előidézője, részben okozója éppen a fenti, a realitástól elrugaszkodott - ahogy a szerző megállapítja, tulajdonképpen a vitorlás hadihajók korából származó - részben anakronisztikus szabályzás. Mivel a hivatkozott esetek egy kivétellel (a Wilheml Gustloff német kirándulóhajót az orosz S-13 jelü tengeralattjáró torpedózta meg) a német búvárhajó-flotta hajóival történtek, érdekes kiegészítés a japán és az amerikai tengeralattjáró tevékenységére vonatkozó rövid tájékoztató. A történeti áttekintés az atomkorszak fejlesztési eredményeinek bemutatásával zárul, Hyman G. Rickover, a legendás amerikai mérnök-tengernagy érdemeinek jelzése mellett. Kajtár István szinte minden tanulmányában tetten érhető a hajókat múködtető emberek, pályafutások ismertetése. Ez a tanulmány tizenhárom német tiszt szakmai életrajzát mutatja be Karl Dönitz tengernagytól Otto Weddigenen és Günther Prienen át Erich Toppig. Nem marad el a korlátlan tengeralattjáró-háború résztvevőinek, a búvárhajó és a célpontja legénységeinek az életkörülményeiről, valamint a tengeralattjáró-vadászatról szóló érzékletes beszámoló sem. Ezek és a tengeralattjárókat ért veszteségek leírása segítenek az olvasónak átérezni ezeknek a tengerészeknek a sorsát, áldozatait. Természetesen a téma jogi kultúrtörténeti elemzése is része ennek a tanulmánynak, így a tengeralattjárósoknak adományozott kitüntetések, az indulók, a hajóra festett képek, mint például Prien, aki híres akcióját követően a Scapa Flow bikája jelzőt kapta és ez az ábra megjelent hajójának, az U-47-nek a tornyán is. A tanulmány a tengeralattjárókkal foglalkozó irodalmi válogatással zárul: a felsorolt hatvankilenc múből az érdeklődő részletesen tájékozódhat a témával kapcsolatban.

\section{Zárszó}

Kajtár Istvánt a Szent István Tudományos Akadéma a rendes tagjai közé fogadta. Laudációját Visegrádi Antal egyetemi tanár, az MTA doktora mondta el. A székfoglaló előadását A joghistória és annak holdudvara címmel ${ }^{53}$ 2017. november 06-án tartotta. Az erről az eseményrôl szóló levelében így ír: „Pályazárónak tartom ezt az eredményes napot - most pedig jöhet a baditengerészeti kedvtelés!”. E kedvtelés körében 2013 óta rendszeresen, néhány havonta találkoztunk és beszélgettünk.

\footnotetext{
${ }^{53}$ Ezt a címet később megváltoztatta. Az új cím Jogi kultúrtörténet lett.
} 
Összegyűjtött anyagai, tudományos hagyatékának egy része valamint a vele készült interjứ ${ }^{54}$ alapján a következő témákban készült még tanulmányt írni:

a) Szevasztopol ostromai: a tanulmány anyagát összegyűjtötte, szóban másfél órás előadást tartott róla, 7 színes térképét megrajzolta, de megírására nem került sor.

b) A japán tengeralattjáró fegyvernem értékelése.

c) a Az 1915-ben Gallipolinál történt tengeri műveletek. ${ }^{55}$

d) A cirkáló fegyvernem története az I. világháborúban.

e) A szovjet flotta tevékenysége 1941 és 1945 között

f) A török birodalom tengeri tevékenysége, melyből a lepantoi csatáról szóló tanulmány készült el.

g) Napoleon flottájának harcai.

Kajtár István hajózási tárgyú munkái jól illenek egyik fő kutatási területe, a jogi kultúrtörténet körébe. Annak ellenére, hogy a hajózással kapcsolatos tevékenységét mindvégig kedvtelésként, hobbiként említette, a tárgyban írt munkái vitathatatlanul tudományos igényűek és jól beleillenek a jogi kultúrtörténet körébe, melynek ebben a témában ő volt az egyik első magyar múvelője. Saját bevallása szerint tervezte, hogy cikkeit, a tervezett továbbiakkal együtt egy könyvbe szerkeszti és kiadja a Fejezetek a tengeri háborúk jogtörténetéböl cím alatt. Ha ez megjelenik, akkor a hazai jogi kultúrtörténet hiánypótló mûvel gazdagodott volna, a laikus érdeklődők tájékoztatásában pedig olyas szerepet tölthetett volna be, mint Benedek István művei az elmekórtan vagy éppen a francia impresszionizmus bemutatásában. Nemcsak a hajózás, hanem általában a történelem iránt érdeklődőknek is nagy veszteség, hogy a könyv megírására nem volt lehetôsége.

Maga is említette, hogy nem az a pedagógus, aki tanít, hanem az, akinek tanítványai vannak. Én hálatelt szívvel nevezem magam a tanítványának. ${ }^{56}$

\section{Felhasznált irodalom és források}

BALOGH Tamás - CSEPREgI Oszkár: A Szent István csatahajó és a csatahajók rövid története. Budapest é.n. CSONKARÉTI Károly: Az Osztrák-Magyar Monarchia haditengerészete. Budapest 2001

GULAS, Stefan - LESCINSKY, Dusan: A vitorlás hajók története. Bratislava1984

JeNTSCHuRA, Hans Georg - Jung, Dieter - MiCKEL, Peter: Warships of the Imperial Japanese Navy 1869-1945. Annapolis (reprint) 1996

KAJTÁR István: Der Schiffskommandant in der neuern Rechtsgeschichte. In: BÉLI Gábor et al. (szerk.): Institutions of Legal History with special regard to the legal culture and history. Bratislava - Pécs 2011, 301-311.

KAjTÁR István: A hadihajókat eladják, ugye? Új Magyarország 1992. április 11. sz. 6.

KAJTÁR István - SZEKERES Róbert: A tengerek és a hajózás jogtörténete kurzus vizsgaanyaga. Msc. Pécs 2003

\footnotetext{
${ }^{54}$ SCHMELCZER-POHÁNKA, Riport Kajtár István jogászprofesszorral nyugdíjba vonulása alkalmából 161-169.

55 Ennek anyagát nagyrészt összegyüjtötte, de megirását későbbre halasztotta, mert közben megjelent egy azonos témájú cikksorozat Kiss Lász̧ló tollából, és ehhez képest kívánt további kutatást végezni és újdonságokkal szolgálni.

${ }^{56}$ A közös maritim hobbink műveléséhez nyújtott támogatásáért köszönetet mondok Kajtár Istvánnénak, Kajtár Editnek és Kajtár Dávidnak, a jelen írás elkészítéséhez nyújtott segítségért pedig tanítványának, Herger Csabáné Eszternek.
} 
KAJTÁR István: CsS Alabama. Adalék a tengeri háborúk jogtörténetéhez. Jura 1997/1. sz. 14-20.

KAJTÁR István: Német segédcirkálók a második világháborúban: A tengeri kaméleonok. Rubicon 1999/5-6. sz. 82-83.

KAJTÁr István: A tengeri zsákmányjogról. Tudományos Dialog: Jogtörténeti Különszám, Pécs 2000, 7-14.

KAJTÁR István: A Mediterráneum tengerjogának történetéhez. Jogtörténeti Szemle 2004/4. sz. 71-77.

KAJTÁR István: A magyar tengerjog matuzsálemei: Az Editto politico di navigazione marcantile (1774) és a Code de Commerce II. Du commerce maritime (1807). In: MEZEY Barna - RÉVÉSZ T. Mihály (szerk.): Ünnepi tanulmányok Máthé Gábor 65. születésnapja tiszteletére. Budapest 2006, 225-245.

KAJTÁR István: Egy hatalmi jelkép kultúrtörténeti gyökerei: A sas. Jura 1994/4. sz. 11-17.

KAJTÁR István: A császári és királyi haditengerészet jelképei - jogtörténeti háttérrel. Jura 2007/2. sz. 184-188.

KAJTÁR István: Az osztrák-magyar haditengerészet jelképeiről. In: BENE Krisztián - DÁvID Ferenc - SARLÓs István (szerk.): Válogatás a Hadtörténeti esték 2006 és 2010 között elhangzott előadásaiból. Pécs 2011, 83-96.

KAJTÁR István: Hadihajónevek a tengeri hatalom szimbólumrendszerében. In: MEZEY Barna (szerk.): A szimbólumok üzenete: a jogi kultúra jelképei: eljárások, szokások, formák és tárgyak. Budapest 2011, 255-267.

KAJTÁR István: Machtsymbole auf der See. In: SzEKERES Róbert (szerk.): Rechtsgeschichte: Gedanken für Gegenwart und Zukunft. Pécs 2005, 46-67.

KAJTÁR István: Az antik görögök tengeri háborúi a Kr. e. V. században. In: MÁTHÉ Gábor - RÉVÉSz T. Mihály GOSZTONYI Gergely (szerk.): Jogtörténeti Parerga: Ünnepi Tanulmányok Mezey Barna 60. születésnapja tiszteletére. Budapest 2013, 182-187.

KAJTÁR István: Lepanto, 1571. október 7. In: BENE Krisztián - DÁvID Ferenc - SARLÓs István (szerk.): Válogatás a Hadtörténeti esték 2006 és 2014 között elhangzott előadásaiból. Budapest - Pécs 2014, 139-162.

KAJTÁR István: Tengeralattjárók. In: BIRó Zsófia - JusZTINGER János - PÓKECZ KOVÁcs Attila (szerk.): Antecessores Iuris Romani. Óriás Nándor és Benedek Ferenc emlékezete: Tanulmányok a római jog és a jogtörténet köréből. Pécs 2016, 217-232.

KISS László: Gallipoli, 1915 - a tengeri hadműveletek I. Haditechnika 2012/2. sz. 6-10.

KOCHER, Gernot: Szimbólumok és jelek a jogban. Történeti ikonográfia. Pécs 2008

MARSAI Viktor: Szomália és kalózai. Haditechnika, 2011/4. sz. 13-16.

NÉMETH Ernő - SÁRHIDAI Gyula: A vasúti tüzérsség általános jellemzői és egyes típusai I. Haditechnika 2017/1. sz. $56-57$.

PEMSEL, Helmut: Seeherrschaft. Eine maritime Weltgeschichte von den Anfängen der Seefahrt bis zur Gegenwart. Band 1: Beginn der Seefahrt bis 1850. Koblenz 1985

SCHMELCZER-POHÁNKA Éva: Riport Kajtár István jogászprofesszorral nyugdijba vonulása alkalmából. Per Aspera Ad Astra 2014/1. sz. 161-169.

STIPTA István: A jogi kultúrtörténet Magyarországon. In: BÉLI Gábor - KORSÓSNÉ DELACASSE Krisztina - HERGER Csabáné (szerk.): Ut Iuris Ordo Exigit-Ünnepi tanulmányok Kajtár István 65.születésnapja tiszteletére. Pécs 2016, 305-313.

SZABÓ Miklós: 300 éves az orosz haditengerészet III. Haditechnika, 1997/2. sz. 16-20.

SZABÓ Miklós: Az orosz Borej tengeralattjáró hajóosztály. Haditechnika, 2016/2. sz.61-63.

SZABÓ Miklós: A 971 típusú, atomhajtású vadász-tengeralattjáró. Haditechnika, 2001/4. sz. 28-31. 